\title{
Dystocia due to Fetal Goiter in a Goat
}

\author{
Navdeep Singh $^{1}$, G.P.S. Sethi ${ }^{2}$, S.P.S. Ghuman ${ }^{3}$ and Kuldip Gupta ${ }^{4}$
}

${ }^{1}$ Directorate of Livestock Farm, ${ }^{2}$ Department of Veterinary Gynaecology and Obstetrics, ${ }^{3}$ Department of Teaching Veterinary Clinical Complex, ${ }^{4}$ Department of Veterinary Pathology, Guru Angad Dev Veterinary and Animal Sciences University, Ludhiana - 141004

*Corresponding author

\section{A B S T R A C T}

\section{Keywords}

Congenital goiter,

Goat, Dystocia,

Thyroid gland, Iodine deficiency

Article Info

Accepted:

07 December 2018

Available Online:

10 January 2019

\section{Introduction}

Goiter is a common anomaly in goats characterized by non-inflammatory and nonneoplastic enlargement of thyroid gland (Ani et al., 1998). Low iodine intake or failure to get dietary iodine is the common cause of congenital goiter in kids (Bires et al., 1996). The present report describes an unusual case of congenital fetal goiter in two kids leading to dystocia.

\section{Case history and observations}

A five-year-old full term pregnant doe in her third parity was brought to university veterinary hospital with the history of severe straining and recumbency for the last 7-8h. Vaginal examination revealed a fully dilated cervix with moist birth canal. The fetus, without any reflex, was in anterior longitudinal presentation with severe lateral deviation of head. The hooves of both the anterior limbs were extended into the birth passage. An unsuccessful traction was tried at field level to deliver the fetus.

\section{Treatment}

The birth passage was well lubricated using $1 \%$ sodium carboxymethyl cellulose gel. After 
assessing the fetus, the correction of deviation was tried but failed. Thereafter, the forelimbs were repelled into uterus and traction was applied by grabbing hind limbs to deliver dead fetus in posterior presentation.

Second fetus with similar presentation, position and posture was delivered by following the same procedure, however, the live fetus died after few minutes of delivery. The goat was discharged with the routine prescription of antibiotics and supportive therapy.

\section{Gross examination and histopathology}

On gross examination, the skin of both kids was without hair, pale and thick with myxedema (Fig. 1). Such type of the condition is described as congenital goiter (Cheema et al., 2010).

Fig.1 Congenital goiter in goat kids

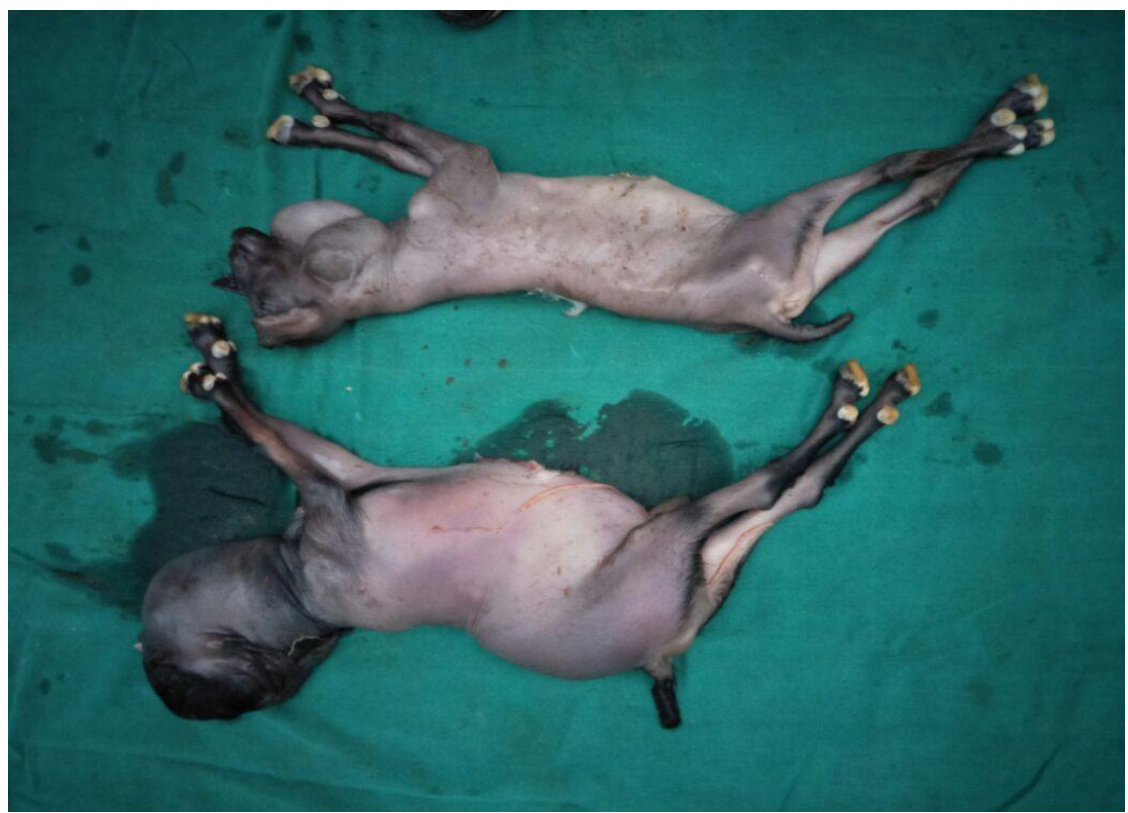

Fig.2 Histological picture of goat thyroid showing colloid goitre with flattened epithelium

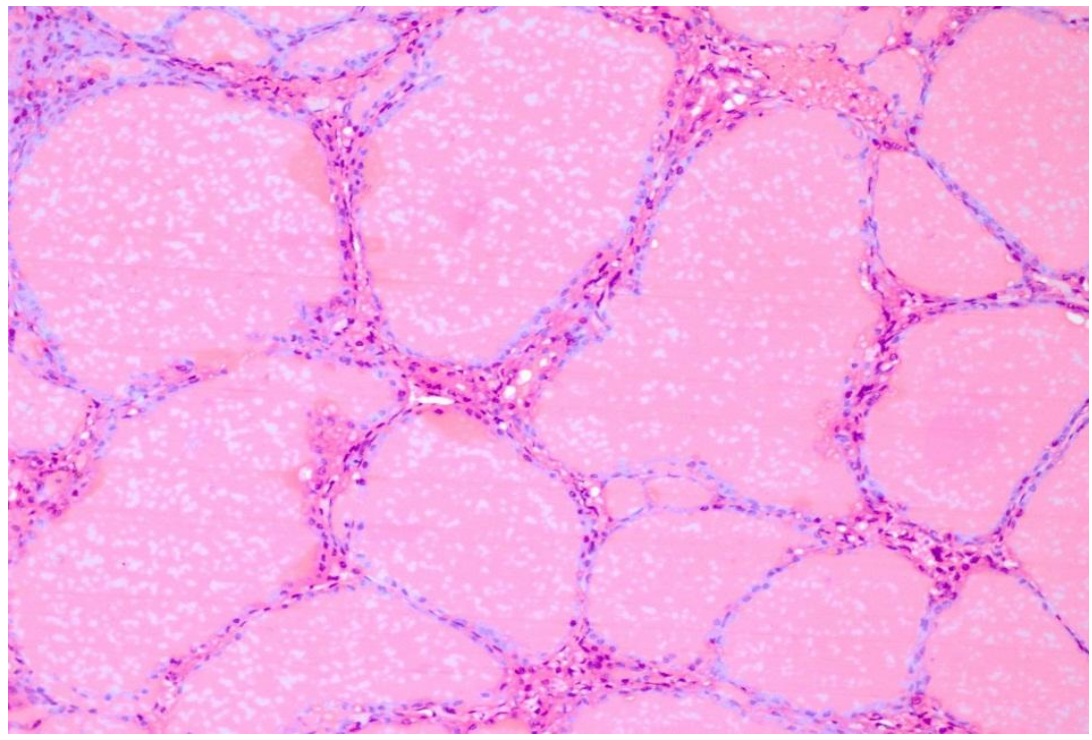


One kid having enlarged abdomen was suggestive of ascites. The tongue of both kids was swollen and protruded from mouth alongwith an enlargement in the upper neck region. Removal of skin from the neck region revealed two massive lobes of enlarged thyroid glands. These were firm, solid and dark brown to red in color. Congenital goiter with alopecia and myxedema was diagnosed on the basis of gross appearance.

Tissues from two lobes were processed by routine histological procedure. Tissue sections were cut at $4 \mu \mathrm{m}$ thickness and stained by routine haematoxyline and eosin method. Thyroid tissue consisted of varying sized thyroid follicles full of colloidal material with hyperplasia of lining epithelium in places but lined by a single layer of cuboidal epithelium (Fig. 2). A marked variation was noted in the contents of follicles and appearance of the lining epithelium in different parts of the gland.

The main reason for the development of thyroid hyperplasia is iodine deficient diets (Paulikova et al., 2002). However, other reasons may be feeding of goitrogenic compounds and/or plants and genetic enzyme defects in biosynthesis of thyroid hormones (McDonald and Pineda, 1989). According to a study, iodine intake was low in buffaloes and cattle of Ludhiana, Jalandhar, Ferozepur and Hoshiarpur districts of Punjab (Randhawa and Randhawa, 2001; Singh et al., 2006). Moreover, in Ludhiana district of Punjab, low soil iodine content and occurrence of endemic goiter (assessed by thyroid palpation) in school children were observed (Jain, 1990).

In the present case, enlarged thyroid glands deviated the head of the fetus leading to dystocia. However, the rotation of fetus inside uterus for changing its presentation from anterior to posterior was helpful in delivery of kid. In summary, a rare case of dystocia due to congenital goiter in a goat kid is reported.

\section{References}

Ani, A.F.K., Khamas, W.A., Qudah, K.M.A. and Rawashdah, O.A. 1998. Occurrence of congenital anomalies in Shami breed of goats; 221 cases investigated in 19 herds. Small Ruminant Research,28, 225-232.

Bires, J., Bartko, P., Weissona, T., Michna, A. and Matisak, T. (1996). Iodine deficiency in Goats as a cause of congenital goitre in kids. Veterinary Medicine,41(5), 133-138.

Cheema, A.H., Shakoor, A. and Shahzad, A.H. 2010. Congenital goitre in goats. Pakistan Veterinary Journal, 30(1), 58-60.

Jain, R. 1990. Dietary intake of iodine in selected goitre endemic and non- endemic areas of Punjab. Ph.D. Dissertation, Punjab Agricultural University, Ludhiana, India.

McDonald, L.E. and Pineda, M.H. 1989. Veterinary Endocrinology and Reproduction. 4th Edition, Lea and Febiger, Philadelphia, USA.

Paulikova, I., Kovac, G., Bires, J., Paulik, S., Seidel, H. and Nagy, O. 2002. Iodine toxicity in ruminants. Veterinarni Medicina, 47(12), 343-350.

Randhawa, C.S. and Randhawa, S.S. 2001. Epidemiology and diagnosis of subclinical iodine deficiency in crossbred cattle of Punjab. Australia Veterinary Journal, 79, 349-351.

Singh, R., Randhawa, S.S. and Randhawa, C.S. 2006. Iodine status of crossbred cattle from sub- mountainous areas of Punjab. Indian Veterinary Journal, 283, 181-184.

\section{How to cite this article:}

Navdeep Singh, G.P.S. Sethi, S.P.S. Ghuman and Kuldip Gupta. 2019. Dystocia due to Fetal Goiter in a Goat. Int.J.Curr.Microbiol.App.Sci. 8(01): 641-643.

doi: https://doi.org/10.20546/ijcmas.2019.801.071 